\title{
Egg Albumin Supplementation Decreases Isolation- Induced Aggression in Male White Mice
}

\author{
Francis S. Legario ${ }^{1,2^{*}}$ and Maureen Antonette D. Bereber ${ }^{1}$ \\ ${ }^{1}$ St. Paul University Iloilo, Gen. Luna St., Iloilo City; \\ ${ }^{2}$ Western Visayas College of Science and Technology, La Paz, Iloilo City
}

\begin{abstract}
There is a need to search for solutions of minimizing aggression so as to minimize violence. The purpose of the study is to determine the effects of different levels of egg albumin supplementation to the aggressive behavior of male white mice (Mus musculus). Specifically, this study aimed to describe aggressive tendencies by isolation-induced fighting of male white mice when fed different levels of egg albumin; determine aggressive behavior in terms of the number of attacks and body scars when fed different levels of egg albumin; and measure dominant-subordinate status when fed different levels of egg albumin. White mice were chosen as test animals since they have homologous genes coding with humans. Furthermore, aggression tends to be more common among male mice than female mice. T-test results showed that there is a significant difference in the aggressive behavior between the treated and untreated mice in all treatments except for Treatment $\mathrm{D}$ (negative control) in terms of number of attacks and body scars and a significant difference in all treatments in terms of the dominant-subordinate status. Analysis of Variance (ANOVA) showed a significant difference in the number of attacks and the dominantsubordinate status. Overall, results showed that egg albumin supplementation reduced aggression in male white mice regardless of the level of egg albumin. It was concretely shown that treatments fed with varied levels of egg albumin significantly alleviated aggressive behavior compared with treatments without egg albumin supplementation.
\end{abstract}

Keywords: albumin, aggression, tryptophan, serotonin

\section{INTRODUCTION}

In everyday life, we use the word "aggression" to cover a range of behaviors, from hurtful comments to violent killings. The word is sometimes even used to describe assertive behavior. In social psychology, aggression is defined as behavior intended to injure another (Kenrick, et al., 2002).

Moreover, aggression, according to Akert et al. (2010), is a disposition or a behavior that implies force, an attack and is hostile. It may arise either in reprisal or without annoyance or provocation. In narrower definitions that are used in social sciences and behavioral sciences, aggression is an intention to cause harm or an act intended to increase relative social dominance. Predatory or defensive behavior between members of different species may not be considered aggression in the same sense. Aggression has different forms and can be physical or be communicated verbally or non-verbally.

According to Southwick (1970), mice are habitually used as a model for human behavior, such as aggression, given that mice and humans have homologous genes coding 
for homologous proteins that are used for comparable functions at some biological levels.

In mice aggression, as indicated by Bock and Goode (1996), males with the identical genotypes were more likely to fight than males that encountered males of other genotypes. Another appealing judgment in mice dealt with mice reared alone. These mice showed a strong inclination to attack other male mice upon their first exposure to the other animals. The mice reared alone were not taught to be more aggressive; they simply exhibited the behavior. This implicates the natural tendency related to biological aggression in mice because the mice reared alone lacked a parent to show them when to be aggressive.

Olivier and Young (2002) stated that several paradigms are used to study aggressive behavior. Some of these are isolation-induced offensive behavior (mouse), residentintruder offensive behavior (rat/mouse/hamster), offensive behaviour after electrical stimulation of the brain (rat), and offensive play-fighting among juvenile rats.

Meanwhile, there are drugs/ substances that can decrease aggressive behavior especially in humans. One of these is fluoxetine which is the drug that was used in the conduct of this study in order to compare the effects of egg albumin in alleviating aggressive tendencies. Fluoxetine, as stated by Ogbru (2012), is used in treating anxiety and depression that trigger aggression. However, fluoxetine is expensive and is not an over-thecounter drug. It also has several side effects which include nausea, anxiety, headache, drowsiness, decreased appetite, insomnia, increased sweating, etc.

Studies have shown that tryptophan, an amino acid which is the precursor of serotonin, has been found to have an effect on aggression. Low tryptophan diet was found to be associated with decreased brain serotonin and increased aggression (Werbach, 1995). Tryptophan intake is inversely correlated with aggressiveness in humans. Dougherty et al. (1999) stated that there is a well-established relationship between aggression and lowered serotonin neuro-transmission and that diet manipulation using tryptophan positively lowers aggression. However, pure L-tryptophan is very expensive such that alternative source for supplementation in the diet is essential. Tryptophan is naturally occurring most significantly in egg whites (Emmanuelson, 2010). Around $28 \mathrm{~g}$ of dried egg white contains approximately $999 \mathrm{mg}$ or almost a gram of tryptophan. Thus it was considered in this study to use egg white as dietary source of tryptophan.

Thus, this study was conducted in order to provide cheaper and natural alternatives to expensive drugs in alleviating aggression.

\section{MATERIALS AND METHODS}

Research Design

This study made use of the Randomized Complete Block Design or RCBD. There were five treatments which were replicated three times. The study underwent two trials.

The treatments were:
A $-15 \%$ egg albumin
B - $10 \%$ egg albumin
C - $5 \%$ egg albumin
D-(negative control)-without egg albumin
$\mathrm{E}$ - (positive control) - fluoxetine

\section{Setting of the Study}

This study was conducted at St. Paul University Iloilo, Animal Laboratory. The study, specifically on handling of the mice, was reviewed and approved by the Ethics Review Committee of the university. 


\section{Test Animals}

This study used male BALB (Bagg Albino) white mice (Mus musculus) as experimental test animals which were purchased from a local animal breeder. The test animals were mature adult (three to six months of age). There were fifteen pairs of mice per trial. Each pair of mice was put in a separate cage; one was fed in a particular treatment while the other was the control. The test animals underwent the process of acclimatization three weeks prior to the conduct of the study in order for them to be able to adjust to the gradual change in the environment.

Flouxetine dosage was consulted with a local veterinarian. Thus, the method for arriving at a specific dosage for each male white mouse which underwent treatment was:

\section{Mean Weight of Mice $=23.7$ grams}

Given that the recommended daily dosage is $0.05 \mathrm{mg} / \mathrm{g}$, the fluoxetine dosage for each treated male mouse was $1.2 \mathrm{mg}$.

Fluoxetine was given by putting $2.5 \mathrm{mg}$ of it on top of the feed of the mice during feeding period. It was made sure that fluoxetine was taken completely by the mice.

\section{Feed/TreatmentPreparation}

According to Reeves et al. (1993), the following are the recently tested purified diets for rapid growth of young rats and mice or for maintenance of adult rats and mice:

Table 1. Feed formulation for male white mice (Mus musculus).

\begin{tabular}{lllll}
\hline Ingredient & $\begin{array}{l}\text { Maintenance } \\
\text { (Negative Control) }\end{array}$ & $15 \%$ & $10 \%$ & $5 \%$ \\
\hline Basic Diet, g/kg diet & & & & \\
Cornstarch & 465.692 & 465.692 & 465.692 & 465.692 \\
Casein (=85\%) & 180.000 & 153.000 & 162.000 & 171.000 \\
Dextrinized cornstarch & 155.000 & 155.000 & 155.000 & 155.000 \\
Sucrose & 100.000 & 100.000 & 100.000 & 100.000 \\
Egg Albumin & 0.000 & 27.000 & 18.000 & 9.000 \\
Fiber source (cellulose) & 50.000 & 50.000 & 50.000 & 50.000 \\
Mineral mix & 35.000 & 35.000 & 35.000 & 35.000 \\
Vitamin mix & 10.000 & 10.000 & 10.000 & 10.000 \\
L-Cystine & 1.800 & 1.800 & 1.800 & 1.800 \\
Choline bitartrate (41.1\% choline) & 2.500 & 2.500 & 2.500 & 2.500 \\
Tert-butylhydroquinone (TBHQ) & 0.008 & 0.008 & 0.008 & 0.008 \\
\hline
\end{tabular}

Feed was prepared at the Feed Mill of Southeast Asian Fisheries Development Center (SEAFDEC)-Aquaculture Department, Tigbauan, Iloilo.

\section{Duration of Feeding}

Two trials were conducted simultaneously. After three weeks of acclimatization, the male white mice were then subjected to a treatment period of one week. The test animals were fed $4.5 \mathrm{~g}$ everyday in ad libitum (Bowman, 2012). Excess feed per day were weighed in order to determine if the test animals had at least the same amount of feed eaten. Excess feed were thrown.

\section{Data Gathering}

After isolating the male mice in individual housing cages ( $5 \times 5$ in) for one week of treatment period, data were then gathered through thirty minutes of observation wherein 
every pair of mice was subsequently placed together in a cage (Crawley, 2007).

Resident-intruder test took place as soon as the treated mouse was joined by the untreated one. This test determined the number of attacks and number of body scars (Olivier \& Young, 2002). The number of body scars was visually inspected on each mouse.

In measuring dominant-subordinate status, the pair of male white mice was placed in a cylindrical plastic tube with a length of $60.69 \mathrm{~cm}$ and inside diameter of $6.27 \mathrm{~cm}$, and the individual that retreated to one end was scored as the subordinate. It was also observed for an hour (Hahn \& Schanz, 1996).

\section{StatisticalTools}

Mean scores were obtained in order to determine the number of attacks, the number of body scars, and the dominant-subordinate status of the treated and untreated male white mice. A Statistical Package for Social Science (SPSS) version 11.5 was used as provided by the Research Center of SPUI. The alpha value was 0.05 and the critical rejection region was 5 $\%$. One Way Analysis of Variance (ANOVA) was used to determine significant differences among treatment levels. Since results showed a significant difference, Post Hoc Analysis using the Least Significant Difference (LSD) was utilized to compare differences among treatments. T-test for Independent Samples was also used to determine the significant difference between the treated mice and the untreated mice per treatment.

\section{RESULTS}

\section{Descriptive Data Analysis}

Mean scores were obtained in order to determine the number of attacks, the number of body scars and the dominant-subordinate status of the treated and untreated male white mice. A Statistical Package for Social Science (SPSS) version 11.5 was used as provided by the Research Center of SPUI. The alpha value was 0.05 and the critical rejection region was 5 $\%$. One Way Analysis of Variance (ANOVA) was used to determine significant differences among treatment levels. Since results showed a significant difference, Post Hoc Analysis using the Least Significant Difference (LSD) was utilized to compare differences among treatments. T-test for Independent Samples was also used to determine the significant difference between the treated mice and the untreated mice per treatment.

Figure 1 shows that the number of attacks elicited by the untreated white mice in Treatments A, B, C, and E was higher than those that were treated using varied levels of egg albumin. However, the number of attacks elicited by the untreated mice in Treatment $\mathrm{D}$ was lower than the treated one.

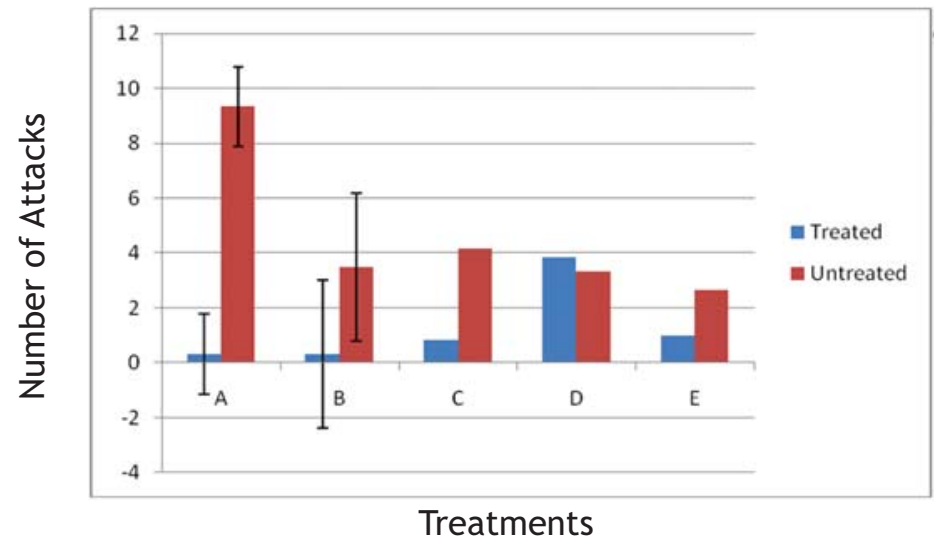

Figure 1. Mean scores for the aggressive behavior in terms of number of attacks 
Figure 2 shows that the number of body scars elicited by the untreated white mice in Treatments A, B, C, and E is lower than those that were treated using varied levels of egg albumin. However, the number of body scars elicited by the untreated mice in Treatment D was higher than the treated one.

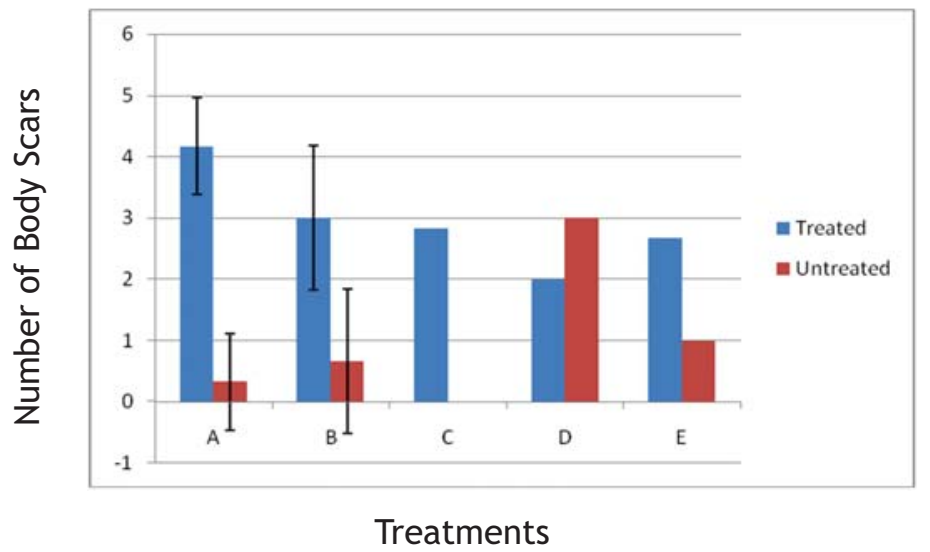

Figure 2. Mean scores for the aggressive behavior in terms of number of body scars

Figure 3 reveals that the treated white mice in Treatments A, B, C, and E scored lower in terms of measuring the dominant-subordinate status than the untreated mice. However, the treated mice in Treatment $\mathrm{D}$ scored higher than the untreated counterpart. Hence, the treated mice in Treatments A, B, C, and E were subordinates while the treated mice in Treatment $\mathrm{D}$ was dominant.

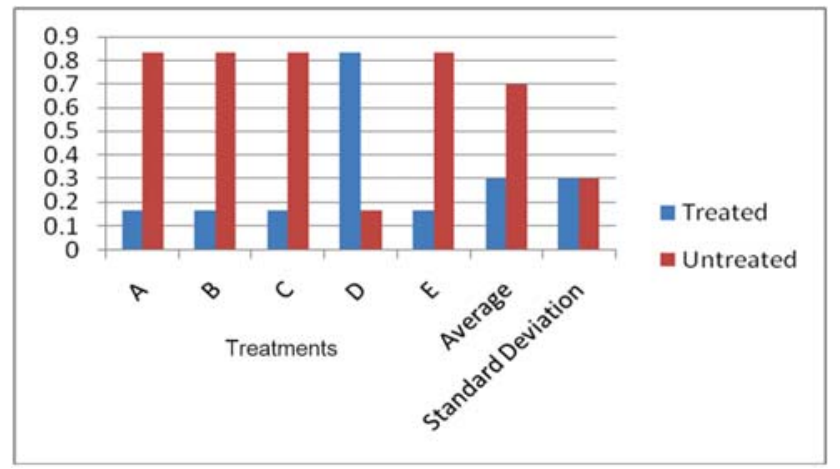

Figure 3. Mean scores for the aggressive behavior in terms of dominant-subordinate status

\section{InferentialData Analysis}

The following results show the ANOVA and t-scores which determined (1) difference in the aggressive behavior of male white mice in terms of the number of attacks when fed different levels of egg albumin; (2) difference in the aggressive behavior of male white mice in terms of the number of body scars when fed different levels of egg albumin and (3) difference between the dominant-subordinate status of male white mice when fed different levels of egg albumin.

Table 1.1 shows that there were significant differences in the aggressive behavior of male white mice in terms of number of attacks using treatments A, B, C, and the positive control. However, it was found that there was no significant difference in the aggressive behavior of male white mice in terms of the number of attacks using the negative control. 
Table 1.1. T-test for the significance of the difference in the aggressive behavior of male white mice in terms of the number of attacks.

\begin{tabular}{ccccccc}
\hline \multirow{2}{*}{ Treatments } & \multicolumn{2}{c}{ Means } & \multirow{2}{*}{ Tf } & df & \multirow{2}{*}{ interpretation } \\
& Treated & Untreated & & & & \\
\hline Treatment A & .333 & 4.667 & -8.062 & 10 & .000 & Significant \\
Treatment B & .333 & 3.500 & -5.836 & 10 & .000 & Significant \\
Treatment C & .833 & 4.167 & -5.872 & 10 & .000 & Significant \\
Treatment D & 3.833 & 3.333 & .785 & 10 & .451 & Not Significant \\
Treatment E & 1.000 & 2.667 & -2.331 & 10 & .042 & Significant \\
\hline
\end{tabular}

$\mathrm{p} \leq 0.05$, significant

Table 1.2 shows that there were significant differences in the aggressive behavior of male white mice in terms of number of body scars using treatments A, B, C, and the positive control. However, it was found that there is no significant difference in the aggressive behavior of male white mice in terms of number of body scars using the negative control.

Table 1.2. T-test for the significance of the difference in the aggressive behavior of male white mice in terms of the number of body scars.

\begin{tabular}{ccccccc}
\hline \multirow{2}{*}{ Treatments } & \multicolumn{2}{c}{ Means } & & & \\
& Treated & Untreated & $\mathrm{t}$ & $\mathrm{df}$ & sig & Interpretation \\
\hline Treatment A & 4.167 & .333 & 4.675 & 10 & .001 & Significant \\
Treatment B & 3.000 & .667 & 2.907 & 10 & .016 & Significant \\
Treatment C & 2.833 & .000 & 3.114 & 10 & .011 & Significant \\
Treatment D & 2.000 & 3.000 & -1.936 & 10 & .082 & Not Significant \\
Treatment E & 2.667 & 1.000 & 2.331 & 10 & .042 & Significant \\
\hline
\end{tabular}

$\mathrm{p} \leq 0.05$, significant

Table 2 shows that there were significant differences between the dominantsubordinate of male white mice using all treatments (A, B, C, D, and E).

Table 2. T-test for the significance of the difference in the aggressive behavior of male white mice in terms of the number of dominant-subordinate status.

\begin{tabular}{|c|c|c|c|c|c|c|}
\hline \multirow{2}{*}{ Treatments } & \multicolumn{2}{|c|}{ Means } & \multirow{2}{*}{$\mathrm{t}$} & \multirow{2}{*}{ df } & \multirow{2}{*}{ sig } & \multirow{2}{*}{ Interpretation } \\
\hline & Treated & Untreated & & & & \\
\hline Treatment A & .167 & .833 & -2.828 & 10 & .018 & Significant \\
\hline Treatment B & .167 & .833 & -2.828 & 10 & .018 & Significant \\
\hline Treatment C & .167 & .833 & -2.828 & 10 & .018 & Significant \\
\hline Treatment D & .833 & .167 & 2.828 & 10 & .018 & Significant \\
\hline Treatment E & .167 & .833 & -2.828 & 10 & .018 & Significant \\
\hline
\end{tabular}

$\mathrm{p} \leq 0.05$, significant

Table 3.1 reveals that there is a significant difference in the aggressive behavior of male white mice in terms of the number of attacks when fed different levels of egg albumin.

Table 3.1. ANOVA for the significance of the difference in the aggressive behavior of male white mice in terms of the number of attacks.

\begin{tabular}{lcccccc}
\hline & $\begin{array}{c}\text { Sum of } \\
\text { Squares }\end{array}$ & df & Mean Square & F & Sig. & Interpretation \\
\hline Between Groups & 51.533 & 4 & 12.883 & 14.422 & .000 & Significant \\
Within Groups & 22.333 & 25 & .893 & & & \\
\hline Total & 73.867 & 29 & & & & \\
\hline $\mathrm{p} \leq 0.05$, significant & & & & & &
\end{tabular}


Table 3.1.1 reveals that when results in terms of the number of scars were compared among the treatments, significant difference was seen only in Treatment D (negative control).

Table 3.1.1. LSD for the significance of the difference in the aggressive behavior of male white mice in terms of the number of attacks.

\begin{tabular}{lccc}
\hline \multicolumn{2}{c}{ Treatment vs. Treatments } & Sig. & Interpretation \\
\hline & B & 1.000 & Not significant \\
A & C & 0.368 & Not significant \\
& D & 0.000 & Significant \\
& E & 0.233 & Not significant \\
& & & Not significant \\
B & C & 0.368 & Significant \\
& D & 0.000 & Not significant \\
& E & 0.233 & Significant \\
C & D & 0.000 & Not significant \\
& E & 0.763 & Significant \\
D & E & 0.000 & \\
\hline
\end{tabular}

$\mathrm{p} \leq 0.05$, significant

Table 3.2 reveals that there was no significant difference in the aggressive behavior of male white mice in terms of the number of body scars when fed different levels of egg albumin

Table 3.2. ANOVA for the significance of the difference in the aggressive behavior of male white mice in terms of the number of body scars.

\begin{tabular}{lcccccc}
\hline & $\begin{array}{c}\text { Sum of } \\
\text { Squares }\end{array}$ & df & $\begin{array}{c}\text { Mean } \\
\text { Square }\end{array}$ & F & Sig. & Interpretation \\
\hline Between Groups & 14.867 & 4 & 3.717 & 1.273 & .307 & Not Significant \\
Within Groups & 73.000 & 25 & 2.920 & & & \\
\hline Total & 87.867 & 29 & & & & \\
\hline
\end{tabular}

$\mathrm{p} \leq 0.05$, significant

Table 4 reveals that there was a significant difference in the aggressive behavior of male white mice in terms of the dominant-subordinate status when fed different levels of egg albumin.

Table 4. ANOVA for the significance of the difference in the aggressive behavior of male white mice in terms of dominant-subordinate status.

\begin{tabular}{lcccccc}
\hline & $\begin{array}{c}\text { Sum of } \\
\text { Squares }\end{array}$ & $\mathrm{df}$ & $\begin{array}{c}\text { Mean } \\
\text { Square }\end{array}$ & F & Sig. & Interpretation \\
\hline Between Groups & 2.133 & 4 & .533 & 3.200 & .030 & Significant \\
Within Groups & 4.167 & 25 & .167 & & & \\
\hline Total & 6.300 & 29 & & & & \\
\hline
\end{tabular}

$\mathrm{p} \leq 0.05$, significant

Table 4.1 reveals that when results in between the dominant-subordinate status were compared among treatments, significant difference was seen only in Treatment D (negative control). 
Table 4.1. LSD for the significance of the difference in the aggressive behavior of male white mice in terms of dominant-subordinate status.

\begin{tabular}{lccc}
\hline \multicolumn{2}{c}{ Treatment vs. Treatments } & Sig. & Interpretation \\
\hline \multirow{3}{*}{$\mathrm{A}$} & $\mathrm{B}$ & 1.000 & Not significant \\
& $\mathrm{C}$ & 1.000 & Not significant \\
& $\mathrm{D}$ & .009 & Significant \\
$\mathrm{E}$ & 1.000 & Not significant \\
$\mathrm{B}$ & $\mathrm{C}$ & 1.000 & Not significant \\
& $\mathrm{C}$ & .009 & Significant \\
& $\mathrm{D}$ & 1.000 & Not significant \\
$\mathrm{C}$ & $\mathrm{E}$ & .009 & Significant \\
& $\mathrm{D}$ & 1.000 & Not significant \\
$\mathrm{D}$ & $\mathrm{E}$ & & \\
\hline
\end{tabular}

$\mathrm{p} \leq 0.05$, significant

\section{DISCUSSION}

Aggression, according to Cliffnotes (2012), is a behavior, verbal or physical, intended to physically hurt or harm in some other way another person or thing. Whether aggression is manifested by individuals or groups (including nations), it is the most destructive force in social relations and consequently an important social issue.

Thus, this study was conducted in order to find food alternatives that could alleviate aggression which is egg albumin. Egg albumin contains tryptophan that could decrease aggressive tendencies (Werbach, 1995). In this study, data were gathered through measuring aggressive tendencies such as the number of attacks, the number of body scars, as well as the dominant-subordinate status.

The data which pertained to the mean scores of the number of attacks and body scars revealed that when the male white mice were exposed to various treatments of egg albumin, their aggressive behavior was lessened. This means that the egg albumin can be an effective means of reducing manifestations of aggressive behavior. Since the egg albumin is believed to be rich in tryptophan, the results in this study was supported by Werbach (1995) which states that adding this serotonin precursor in the diet was found to be associated with both increased brain serotonin and decreased aggression. Furthermore, his findings suggest that tryptophan supplementation may be most effective in reducing aggression especially during times of stress just like when the mice are exposed to isolationinduced fighting. Moreover, the findings are also supported by the study of Miczek et al. (2001) and Dougherty et al. (1999) wherein manipulations in the serotonin level of the various animals subjected for observation of aggressive behavior have been found to have significant effects in the manifestations of their aggressive tendencies.

Results, moreover, suggest that dominant-subordinate relationship elicited by the treated white mice in Treatments A, B, C, and E is subordinate than dominantly untreated using varied levels of egg albumin. Given that Treatment D is the negative control, it is expected to score higher among other treated mice in all treatments since it was not treated with egg albumin. This is then affirmed by the above mentioned studies (Werbach, 1995; Miczek et al., 2001; Dougherty et al., 1999) which imply that if serotonin levels are decreased or depleted, the tendency to elicit aggressive behavior, such as becoming dominant, increases. As aggressive behavior starts to escalate, the stress levels brought about by isolation-induced fighting also increases. In addition, using the study of Hahn and Schanz 
(1996) in measuring dominant-subordinate status, it was also affirmed that when mice are exposed to varying levels of tryptophan, such status significantly lowers down.

In the analysis of the inferential data using t-Test, it was found that significant differences in the aggressive behavior of the mice were observed with regard to the number of attacks and number of scars when these mice were and were not exposed to varying treatments of egg albumin. Even if Compaan et al. (1993) stated that fighting among male white mice is common, certain manifestations in their aggressive behaviors such as presence of scars and provoking attacks have been significantly reduced when they were exposed to serotonin precursor substances such as the egg albumin compared to those that were not exposed to such. Thus, the number of attacks as described by Ginsburg and Allee (1942) in which mice took defensive position reduced the probability of scars to be produced.

ANOVA results for scar showed no significant difference among treatments and control groups thus confirming the observations of Ginsburg and Allee (1942).

In the analysis of the significant differences between the dominant-subordinate of male white mice using t-Test (Table 5) for all treatments, it was found that untreated mice significantly elicit dominant status while treated mice show subordinate status (Treatments A, B, C and E). In the case of Treatment D (negative control), results showed a significant difference since male white mice exhibit more dominant status than the other mice (untreated).

In the inferential data analysis using ANOVA, it was found that there was a significant difference in the aggressive behavior of male white mice in terms of the number of attacks (Table 6.1) when fed different levels of egg albumin including the negative and positive controls. However, in terms of the number of body scars, it was found that there was no significant difference in the aggressive behavior of male white mice.

The results in Table 6.1.1 (LSD Table) showed that the male white mice that were exposed to different dosages of egg albumin as well as those that were given the positive control (Fluoxetine) showed a significant difference in the number of attacks when compared to each other in contrast to those white mice that were in the negative control. This implies that the tendency of the male white mice to elicit manifestation of aggressive behavior for all treatments except for Treatment $\mathrm{D}$ (negative control) did not considerably differ. On the other hand, when Treatments A, B, C, and E were compared to Treatment D, results revealed that male white mice fed without egg albumin tended to attack more. The results were affirmed from the study of Dougherty et al. (1999) wherein he stated that egg albumin supplementation decreases aggression through its tryptophan content.

Reported as no significant difference (ANOVA) in terms of number of body scars, it is primarily because as the untreated mice attacked the treated mice (Treatments A,B,C,E), the treated mice avoided the attack coming from the other that might have led to absence of scar among the treated mice. Since their aggression was toned down due to the egg albumin and the positive control (Fluoxetine), they were latent to the attacks of the untreated mice. Whereas other treated mice did not have the chance to avoid the attacks coming from the untreated mice, therefore giving them several body scars. Some treated mice (two replicates) even got killed due to the attack of the untreated mice. Even though it was reported to be not significant in terms of the number of body scars, still the significance lies on the number of attacks since the number of body scars is just a product of the attacks coming from the untreated mice.

The ANOVA results (Table 4) for the dominant-subordinate status of the male white mice were found to be significantly different. This explains that egg albumin has significant effects in the dominant-subordinate of male white mice. Thus, these findings can be supported by the study conducted by Miczek, et al (2001) which states that when egg albumin is supplemented in the diet, the tendency to be aggressive which includes dominant behavior is reduced. 
The results in Table 4.1 (LSD Table) showed that the male white mice that were exposed to different dosages of egg albumin as well as those that were given the positive control did not elicit a significant difference in their dominant-subordinate status when compared to each other in contrast to those white mice that were in the negative control. This implies that the tendency of the male white mice to elicit manifestation of subordinate status in all treatments except for Treatment D (negative control) did not considerably differ. On the other hand, when Treatments A, B, C, and E were compared to Treatment D, results revealed that male white mice fed without egg albumin tended to elicit aggressive behavior, specifically dominant status.

The study also shows that all concentration levels showed the same effect in lowering down the aggressive behavior. This result shows that at $5 \%$ egg albumin supplementation is high enough to decrease aggressive behavior in male white mice. They are also comparable (no significant difference) with the positive control which is Fluoxetine. From this, we can say that even at lower egg albumin concentration, the desired effect is still the same; thus, there is no need to use higher levels of concentration.

In conclusion, the study showed that egg albumin supplementation toward mice reduces aggressive behavior regardless of the level of egg albumin. It was concretely shown that treatments fed with varied levels of egg albumin significantly alleviate aggressive behavior compared with treatments without egg albumin supplementation. It was also observed that treatments with egg albumin could reduce aggression of male white mice equally with the positive control which is Fluoxetine. Thus, egg albumin showed a potential property to be used in the treatment of aggression.

Further research can be done to determine if lower levels (less than $5 \%$ ) of egg albumin can still lower the aggressive behavior in male white mice. Moreover, this study can be used as basis to do research on animals of agricultural importance with inherent aggressive behaviors (e.g. chicken, pigs).

\section{REFERENCES}

AKERT R.M., E. ARONSON, and T.D. WILSON. 2010. Social Psychology (7th ed.). Upper Saddle River, NJ: Prentice Hall.

BOCK G.R., and J.A. GOODE. 1996. Genetics of Criminal and Antisocial Behaviour. J. biosoc. Sci. 30, 135-144.

BOWMAN C. 2012. What do mice eat. [Internet]. [cited 2012 November 26]; Available from http://www.life123.com/parenting/pets/pet-rodents/what-do-mice-eat2.shtml

CLIFFNOTES. 2012. Aggression. [Internet]. [cited 2012 March 10]; Available from http://www.cliffsnotes.com/study_guide/Aggression.topicArticleId25438,articleId-25408.html

COMPAAN J.C., G. van Wattum, A.J. de Ruiter, G.A. van Oortmerssen, J.M. Koolhaas, and B. Bohus 1993. Genetic Differences in Female House Mice in Aggressive Response to Sex Steroid Hormone Treatment. Physiology and Behavior. 54: 899-902.

CRAWLEY J.N. 2007. Social behavior tests for mice. Laboratory of behavioural neuroscience. National Institue of Mental Health, Bethesda, Maryland.

DOUGHERTY D.M., F.G. MOELLER, J.M. Biork, and D.M. Marsh. 1999. Plasma Ltryptophan depletion and aggression. Adv ExpMed Biol. 467:57-65.

EMMANUELSON, J. (2010). The tryptophan story. Retrieved July 11, 2012 from http://www.futurescience.com/tryptoph.html

GINSBURG B., and W.C. ALLEE. 1942. Some effects of conditioning on social dominance and subordination in inbred strains of mice. PhysiolZoo. 15:485-506.

HAHN M.E., and N. SCHANZ.1996. Issues in the genetics of social behaviour: revisited. Behav Genet. 26:463-470. 
KENRICK D., S. NEUBERG, and R. CIALDINI. 2002. Social Psychology: Unraveling the Mystery $2^{\text {nd }}$ Edition,. Boston, MA: A Pearson Education Company, 10:337.

MICZEK K.A., S.C. MAXSON, E.W. FISH, and S. FACIDOMO. 2001. Aggressive behavioural phenotypes in mice. Behav Brain Res 125:167-181.

OGBRU O. 2012. Fluoxetine, prozac, sarafem. [Internet]. [cited 2012 November 11]; Available from http://www.medicinenet.com/fluoxetine/article.html

OLIVIER J., and L. YOUNG. 2002. Animal models of aggression. Neuropsychopharmacology: The Fifth Generation of Progress. 118:1700-5.

REEVES P.G., F. H. NIELSEN, and G.C. FAHEY, Jr. 1993. AIN-93 purified diets for laboratory rodents: Final report of the American Institute of Nutrition Ad Hoc Writing Committee on the reformulation of the AIN-76A rodent diet. J. Nutr. 123:1939-1951.

SOUTHWICK C.H. 1970. Animal Aggression: Selected Readings. London: Litton Educational Publishing Inc.

WERBACH M. 1995. Aggressive behaviour and L-Tryptophan. Nutritional Influences on Illness. 7:154-6. 